\title{
Penerapan Model Pembelajaran Role Play untuk Meningkatkan Kemampuan dan Hasil Belajar Siswa pada Kompetensi Dasar Prosedur Penanganan Barang Bawaan Tamu
}

\section{Siti Nurul Rahmah*}

SMK Negeri 2 Singaraja

\author{
A R T I C L E I N F O \\ Article history: \\ Received 19 November \\ 2018 \\ Received in revised form \\ 30 December 2018 \\ Accepted 10 January 2019 \\ Available online 20 \\ February 2019 \\ Kata Kunci: \\ Role Play, kemampuan, \\ hasil belajar. \\ Keywords: \\ Role Play, ability, learning \\ outcomes.
}

\begin{abstract}
A B S T R A K
Penelitian ini bertujuan untuk mengetahui sejauh mana penerapan model pembelajaran Role Play dapat meningkatkan kemampuan dan hasil belajar dalam menangani barang bawaan tamu yang tiba di hotel pada mata pelajaran front-office siswa kelas XII AP-3 SMK Negeri 2 Singaraja tahun .pelajaran 2017/2018. Penelitian ini tergolong penelitian tindakan kelas yang dilaksanakan dalam dua siklus, dengan bentuk guru sebagai peneliti. Subyek penelitian yang akan dijadikan penelitian adalah siswa kelas XII AP-3 di SMK Negeri 2 Singaraja, semester ganjil tahun pelajaran 2017/2018. Jumlah siswa 38 terdiri atas 22 siswa laki-laki dan 16 siswa perempuan. Data dianalisis dengan menggunakan analisis statistik deskriptif. Pada siklus I nilai ratarata hasil belajar siswa mencapai 83,6 yang berada pada kategori baik dan meningkat pada siklus II menjadi 89,5 berada pada kategori sangat baik. Tingkat ketuntasan hasil belajar siswa secara klasikal pada siklus I adalah $66 \%$ berada pada kategori baik. Pada siklus II ketuntasan belajar siswa mencapai $100 \%$ dalam kategori sangat baik. Jadi model pembelajaran Role Play dengan seting belajar kelompok dapat meningkatkan kemampuan dan hasil belajar siswa pada kompetensi dasar prosedur penanganan barang bawaan tamu individu saat tiba di hotel pada mata pelajaran Front-office di kelas XII AP-3 Semester Ganjil Tahun Pelajaran 2017/2018.
\end{abstract}

\section{A B S T R A C T}

This study aims at determining the use of Role Play learning model in improving learning outcome and achievement in front office material of handling guest at the hotel of class XII AP-3 students at SMK Negeri 2 Singaraja in academic year 2017/2018. This research is classified as classroom action research conducted in two cycles, with the form of a teacher as a researcher. The research involved students of class XII AP-3 at Singaraja State Vocational High School 2, odd semester of academic year 2017/2018 with the total of 38 students consisting of 22 male students and 16 female students. Data were analyzed by using descriptive statistical analysis. In the first cycle the average value of student learning outcomes reached 83.6 which was in the good category and increased in the second cycle to 89.5 which belonged to a very good category. The level of completeness of student learning outcomes classically in the first cycle was $66 \%$ as a good category. In cycle II student learning completeness reached $100 \%$ in the excellent category. In conclusion, Role Play learning model with group learning setings can improve students' outcome and achievement in front office material of handling guest at the hotel in class XII AP-3 in odd semester of academic year $2017 / 2018$. 


\section{Pendahuluan}

Belajar mengajar pada dasarnya adalah interaksi atau huhungan timbal balik antara guru dan siswa dalam situasi pendidikan. Oleh karena itu, guru dalam mengajar dituntut kesabaran, keuletan dan sikap terbuka di samping kemampuan dalam situasi belajar mengajar.

Salah satu kegiatan pendidikan adalah menyelenggarakan proses belajar mengajar. Belajar sebagai suatu aktivitas mental/psikis yang berlangsung dalam interaksi aktif dengan lingkungan, yang menghasilkan perubahan dalam pemahaman, ketrampilan dan nilai sikap. Belajar dapat membawa perubahan, dan perubahan itu pada pokoknya adalah diperoleh kecakapan baru melalui suatu usaha. Dalam pembelajaran sebaiknya diarahkan kepada kegiatan-kegiatan yang mendorong siswa belajar aktif baik secara fisik, sosial, maupun psikis dalam memahami konsep. Oleh karena itu dalam proses pembelajaran hendaknya guru menggunakan metode yang membuat siswa banyak beraktifitas.

Dengan banyaknya aktifitas yang dilakukan, diharapkan dapat menimbulkan rasa senang dan antusias siswa dalam belajar. Dengan demikian, pemahaman konsep semakin baik dan hasil belajarnyapun akan meningkat. Model pembelajaran yang dapat memberikan hanyak kesempatan kepada siswa untuk aktif terlibat antara lain adalah model bermain peran atau Role Play.

Kompetensi dasar prosedur penanganan barang bawaan tamu merupakan kompetensi keahlian yang penting bagi siswa SMK khususnya program studi akomodasi perhotelan. Kompetensi keahlian ini diberikan pada siswa kelas XII. Pada kompetensi ini peserta didik diajarkan dan dilatih bagaimana seorang petugas bellboy dalam menangani barang bawaan tamu tiba di hotel dengan baik, cepat dan sesuai dengan prosedur kerja.

Penyebab terjadinya kesulitan siswa dalam pembelajaran praktek pada kompetensi dasar prosedur penanganan barang bawaan tamu tiba di hotel, karena siswa masih awam dengan istilah-istilah yang diajarkan dan terbatasnya pengetahuan siswa terhadap materi praktek yang biasanya dilakukan oleh seorang petugas bellboy di hotel. Meskipun siswa mengetahui secara teori prosedur penanganan barang bawaan tamu tiba di hotel, namun siswa belum memiliki gambaran yang jelas tentang langkah-langkah penanganan barang bawaan tamu tiba di hotel yang harus dikerjakan. Terlebih kurangnya kemampuan siswa terbadap penguasaan komunikasi, terutama penggunaan bahasa Inggris. Di sisi lain, mata pelajaran ini merupakan prasyarat untuk diujikan pada uji kompetensi.

Seseorang dikatakan terampil apabila kegiatan yang dilakukan ditandai oleh kemampuannya untuk menghasilkan sesuatu dengan kualitas yang tinggi (cepat atau cermat) dengan tingkat keajegan yang relatif tepat, pembelajaran yang efektif bila dilakukan secara berulang-ulang maka keterampilan baru akan dapat diperoleh.

Berdasarkan penjelasan diatas dapat disimpulkan bahwa kemampuan adalah suatu proses perbuatan atau cara meningkatkan usaha dengan didasari kesanggupan, kekuatan untuk melakukan sesuatu potensi yang dimilikinya.

Hasil belajar menurut Wina Sanjaya adalah sesuatu yang diperoleh siswa sebagai konsekuensi dari upaya yang telah dilakukan sehingga terjadinya perubahan perilaku pada yang bersangkutan baik perilaku dalam bidang kognitif, afektif maupun psikomotorik.

Umumnya hasil belajar itu ditunjukkan melalui nilai atau angka yang diperofeh siswa setelah dilakukan serangkaian proses evaluasi hasil belajar. Besar kecilnya imbalan yang diberikan akan mempengaruhi kepuasan belajar dan setiap kepuasan yang ditimbulkan dari imbalan akan berpengaruh kepada besar kecilnya motivasi. Sedangkan Nana Sudjana berpendapat bahwa hasil belajar adalah kemampuan-kemampuan yang dimiliki siswa setelah ia menerima pengalaman belajarnya.

Salah satu alternatif model pembelajaran yang dapat dikembangkan untuk meningkatkan kemampuan dan hasil belajar adalah model pembelajaran Role Play. Menurut Zuhaerini (1983), model ini digunakan apabila pelajaran dimaksudkan untuk: (a) menerangkan suatu peristiwa yang didalamnya menyangkut orang banyak, dan berdasarkan pertimbangan lebih baik didramatisasikan daripada diceritakan, karena akan lebih jelas dan dapat dihayati oleh anak; (b) melatih anak-anak agar mereka mampu menyelesaikan masalah-masalah sosial-psikologis; dan (c) melatih anak-anak agar mereka dapat bergaul dan memberi kemungkinan bagi pemahaman terhadap orang lain beserta masalahnya.

Sementara itu, Davies dalam artikel Role Play Gogel (2010) mengemukakan bahwa penggunaan Role Play dapat membantu siswa dalam mencapai tujuan-tujuan afektif. Seperti telah dikemukakan di atas, bahwa penggunaan model ini dalam rangka mencapai tujuan pembelajaran yang telah direncanakan. Ada empat asumsi yang mendasari model ini memiliki kedudukan yang sejajar dengan model-model pengajaran lainnya. Keempat asumsi tersebut ialah: Pertama, secara implisit bermain peran mendukung suatu situasi belajar berdasarkan pengalaman dengan menekankan dimensi "di sini dan kini" (here and now) sebagai isi pengajaran. Kedua, bermain peran memberikan kemungkinan kepada para siswa untuk mengungkapkan perasaan-perasaannya yang tak dapat mereka kenali tanpa bercermin kepada orang lain. 
Ketiga, model ini mengasumsikan bahwa emosi dan ide-ide dapat diangkat ke taraf kesadaran untuk kemudian ditingkatkan melalui proses kelompok. Keempat. model mengajar ini mengasumsikan bahwa proses-proses psikologis yang tersembunyi (covert) berupa sikap-sikap nilai-nilai. perasaan-perasaan dan sistem keyakinan dapat diangkat ke taraf kesadaran melalui kombinasi pemeranan secara spontan dan analisisnya. "Role Playing" (bermain peran) sebagai suatu model pembelajaran bertujuan untuk membantu siswa menemukan diri (jati diri) didunia sosial dan memecahkan dilema dengan bantuan kelompok (Uno Hamzah, 2009: 26). Hal ini berarti, melalui bermain peran siswa belajar menggunakan konsep peran, menyadari adanya peran-peran yang berbeda dan memikirkan perilaku dirinya dan perilaku orang lain. Uno juga mengungkapkan bahwa proses bermain peran ini dapat memberikan contoh kehidupan perilaku manusia yang berguna sebagai sarana bagi siswa untuk: (1) menggali perasaannya; (2) memperoleh inspirasi dan pemahaman yang berpengaruh terhadap sikap, nilai dan persepsinya; (3) mengembangkan keterampilan dan sikap dalam memecahkan masalah; (4) mendalami mata pelajaran dengan berbagai cara.

Pembelajaran Role Playing adalah suatu cara penguasasan bahan-bahan pelajaran melalui pengembangan imajinasi dan penghayatan siswa (Hamdani, 2011: 87). Pengembangan imajinasi dan penghayatan itu dilakukan siswa dengan memerankannya sebagai tokoh hidup atau benda mati. Metode ini banyak melibatkan siswa dan membuat siswa senang belajar serta metode ini mempunyai nilai tambah yaitu: (1) dapat menjamin partisipasi seluruh siswa dan memberi kesempatan yang sama untuk menunjukkan kemampuannya dalam bekerja sama hingga berhasil, (2) permainan merupakan pengalaman yang menyenangkan bagi siswa. Permainan pada umumnya dilakukan oleh lebih dari satu orang, bergantung pada apa yang diperankan.

Untuk dapat mengukur sejauh mana bermain peran memberikan manfaat kepada pemeran dan pengamatnya, ditentukan oleh tiga hal, yakni (1) kualitas pemeranan; (2) analisis yang dilakukan melalui diskusi setelah pemeranan; (3) persepsi siswa terhadap peran yang ditampilkan dibandingkan dengan situasi nyata dalam kehidupan. Pembelajaran dengan model Role Play dilaksanakan menjadi beberapa tahap, yaitu sebagai berikut: (1) tahap memotivasi kelompok; (2) memilih pemeran; (3) menyiapkan pengamat; (4) menyiapkan tahap-tahap permainan peran; (5) pemeranan; (6) diskusi dan evaluasi; (7) pemeranan ulang; (8) diskusi dan evaluasi kedua; (9) membagi pengalaman dan menarik generalisasi.

Alasan dipilihnya model ini karena model pembelajaran Role Play merupakan model yang menarik dan dapat menumbuhkan keberanian siswa. Model ini memiliki beberapa kelebihan dibandingkan dengan model pembelajaran lainnya, karena model pembelajaran ini dapat memberikan banyak kesempatan kepada siswa untuk aktif terlibat antara lain adalah metode bermain peran atau Role Play, sehingga siswa lebih mudah memahami materi pelajaran. Melalui metode ini siswa dituntut untuk mengeskpresikan bakatnya masing-masing terkait materi pelajaran yang akan dipelajari. Dengan demikian keaktifan siswa dalam mengikuti pelajaran dan hasil belajar siswa dapat meningkat. Melihat uraian tersebut di atas sangat menarik perhatian penulis untuk melakukan penelitian tindakan kelas dengan judul "Penerapan Model Pembelajaran Role Play untuk Meningkatkan Kemampuan dan Hasil Belajar Siswa pada Kompetensi Dasar Prosedur Penanganan Barang Bawan Tamu Kelas XII AP-3 Semester Ganjil di SMK Negeri 2 Singaraja Tahun Pelajaran 2017/2018.

Berdasarkan latar belakang tersebut, tujuan penelitian ini sebagai berikut: (1) untuk mengetahui sejauh mana penerapan model pembelajaran Role Play dapat meningkatkan kemampuan dalam menangani barang bawaan tamu tiba di hotel pada mata pelajaran Front-office siswa kelas XII AP-3 SMK Negeri 2 Singaraja tahun .pelajaran 2017/2018, (2) untuk mengetahui sejauh mana penerapan model pembelajaran Role Play dapat meningkatkan hasil belajar dalam menangani barang bawaan tamu tiba di hotel pada mata pelajaran Front-office siswa kelas XII AP-3 SMK Negeri 2 Singaraja tahun pelajaran $2017 / 2018$.

\section{Metode}

Jenis penelitian yang digunakan adalah penelitian tindakan kelas (PTK) atau sering disebut classroom action research. Penelitian tindakan kelas merupakan suatu bentuk penelitian yang bersifat reflektif dengan melakukan tindakan-tindakan tertentu agar dapat memperbaiki dan atau meningkatkan praktek-praktek pembelajaran di kelas secara lebih profesional (Kanca, 2006:94).

Menurut Ojan SN (dalam Kanca, 2006:100) mengatakan bahwa ada empat bentuk Penelitian Tindakan Kelas (PTK) yaitu: (1) Guru sebagai peneliti atau peneliti sebagai guru, (2) penelitian tindakan kolaboratif, (3) Simultan terintegrasi, dan (4) administrasi sosial eksperimental. Dalam Penelitian ini, jenis penelitian yang digunakan adalah guru sebagai peneliti, yaitu guru dalam hal ini peneliti berperan sangat penting dalam proses Penelitian Tindakan Kelas. Guru/peneliti terlibat secara penuh dalam proses perencanaan aksi (tindakan), dan refleksi (Kanca, 2006:100). Penelitian Tindakan Kelas pada dasarnya 
merupakan salah satu cara untuk menjadikan pembelajaran menjadi lebih efektif yang akan dilihat dari kemajuan yang telah dicapai siswa.

Metode penelitian yang dilakukan dalam penelitian ini adalah metode Penelitian Tindakan Kelas (PTK) model Kurt Lewin. Konsep pokok PTK menurut Kurt Lewin terdiri dari empat tahapan yaitu: (1) perencanaan, (2) tindakan, (3) observasi/evaluasi, (4) refleksi. Hubungan keempat tahapan itu dipandang sebagai satu siklus. Penelitian ini menggunakan PTK dengan harapan guru Akomodasi Perhotelan dapat memperbaiki kinerjanya sebagai guru dan menciptakan pembelajaran yang bermutu.

Adapun rancangan penelitian ini dapat digambarkan sebagai berikut:

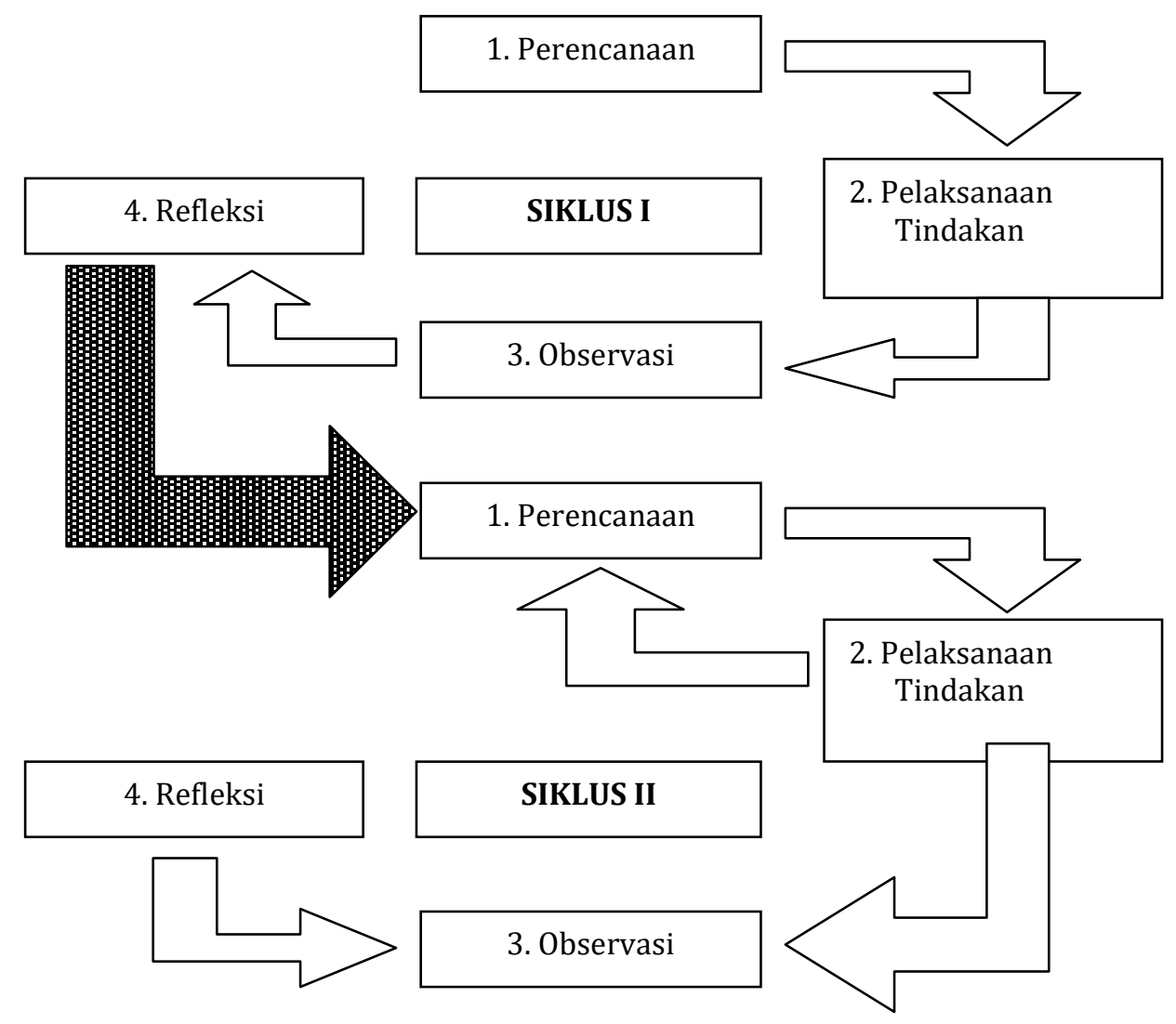

Gambar 3.1 Siklus PTK

Tahapan pelaksanaan penelitian sebagai berikut.

1) Perencanaan atau Rencana Tindakan

Perencanaan berupa menyusun rancangan tindakan yang menjelaskan tentang apa, mengapa, kapan, dimana, oleh siapa dan bagaimana tindakan tersebut akan dilakukan (Kanca, 2006:75). Adapun langkah-langkah yang sudah ditempuh dalam penelitian ini adalah: (1) mengadakan observasi awal pada pembelajaran yang akan diteliti, (3) membuat rencana pembelajaran, (4) menyiapkan strategi pembelajaran, (5) menyiapkan media, sarana prasarana yang diperlukan dan menyiapkan instrumen penelitian berupa lembar observasi dan menyiapkan perangkat tes.

2) Pelaksanaan Tindakan

Pelaksanaan merupakan apa yang dilakukan oleh guru atau peneliti sebagai upaya perbaikan, peningkatan atau perubahan yang diinginkan (Kanca, 2006:111). Untuk mempermudah pelaksanaan tindakan penelitian, maka peneliti menyusun skenario pembelajaran yang akan dilakukan yang mana secara garis besar proses pembelajaran praktek pada mata pelajaran Front-office menggunakan pendekatan kontekstual dengan model pembelajaran Role Play.

3) Observasi/Evaluasi

Observasi atau Evaluasi adalah mengamati atas hasil tes atau dampak dari tindakan yang dilaksanakan atau dikenakan terhadap siswa (Kanca, 2006:111). Observasi dilakukan di setiap pertemuan dengan cara melihat dan mencatat setiap tindakan yang terjadi baik berupa masalah yang ditemui selama pelaksanaan tindakan dan hal-hal positif yang terjadi pada proses pembelajaran. 
4) Refleksi

Refleksi merupakan suatu cara untuk mengkaji, melihat dan mempertimbangkan hasil atau dampak dari tindakan berbagai kriteria (Kanca, 2006:111). Setelah dilakukan evaluasi pembelajaran, kekurangan yang dialami siswa dalam proses pembelajaran penanganan barang bawaan tamu tiba di hotel diperoleh melalui lembar observasi siklus I yang tujuannya untuk mengetahui hasil atau dampak pelaksanaan tindakan. Dari hasil refleksi tersebut dapat disusun rencana untuk siklus berikutnya Masalah-masalah pada siklus I dicari pemecahannya, sedangkan kelebihan-kelebihan dipertahankan untuk ditingkatkan.

Penelitian ini dilakukan di SMK Negeri 2 Singaraja, Bali yang berkokasi di Jalan Srikandi No 9 Singaraja. Penelitian ini dilakukan di kelas XII AP-3 di SMK Negeri 2 Singaraja, semester ganjil tahun pelajaran 2017/2018 pada bulan Agustus sampai dengan November 2017. Jumlah siswa 38 terdiri atas 22 siswa laki-laki dan 16 siswa perempuan. Sedangkan karakteristik siswa di kelas tersebut memiliki karakteristik yang sama seperti kelas-kelas yang lain, artinya tingkat kemampuan hasil belajar hampir sama dengan kemampuan hasil belajar kelas lainnya.

Data hasil belajar dikumpulkan berdasarkan hasil post-test pada masing-masing siklus dan lembar observasi unjuk kerja, sedangkan data mengenai kemampuan belajar dikumpulkan dengan menggunakan lembar observasi unjuk kerja yang merupakan pencatatan secara manual dengan poin-poin indikator yang menjadi acuan atau peta observasi. Penelitian ini menggunakan teknik analisis statistik deskriptif.

\section{Hasil dan Pembahasan}

Berdasarkan analisis data hasil belajar pada siklus I yang diperoleh dari hasil tes dan lembar observasi menunjukkan hasil belajar siswa rata-rata sebesar 83,6 dengan ketuntasan klasikal 66\%. Kreteria Ketuntasan Minimal (KKM) untuk mata pelajaran Front-office pada semester ganjil tahun pelajaran 2017/2018 adalah 85, sementara siswa yang memperoleh nilai sesuai KKM sebanyak 25 dan yang belum memenuhi KKM sebanyak 13 orang.

Berdasarkan hasil pengamatan peneliti selama pemberian tindakan pada siklus I ditemukan beberapa kendala atau hambatan. Kendala atau hambatan tersebut yaitu: siswa kurang teliti dalam menyiapkan formulir yang digunakan pada saat melaksanakan praktek, (1) siswa kurang paham pada saat pengisian data kedalam formulir, (2) siswa kurang serius dalam melakukan praktek penanganan barang bawaan tamu tiba di hotel, (3) saat melakukan praktek siswa lupa dengan urutan atau prosedur penanganan penanganan barang bawaan tamu tiba di hote, (4) waktu penyelesaian praktek masih kurang.

Upaya perbaikan untuk mengatasi kendala tersebut dengan melakukan tindakan, sebagai berikut:

1) Memberikan arahan kepada siswa agar tidak malu bertanya, baik pada temannya maupun pada guru pengajarnya di luar jam pelajaran jika masih ada hal-hal yang kurang dipahami atau dimengerti pada saat melaksanakan praktek, selain itu peneliti juga memberikan kesempatan kepada siswa untuk bertanya sebelum praktek dilaksanakan

2) Memotivasi siswa agar lebih percaya diri dengan memberikan kesempatan pada siswa untuk berartikulasi dan memberikan penghargaan untuk kelompok yang terbaik

3) Mengarahkan kelompok untuk saling kerjasama, dengan membagi tugas pada tiap siswa agar semua kelompok memiliki peran untuk bekerja dalam kelompoknya dan membuat sedikit kemungkinan untuk siswa tidak bercanda

4) Menyampaikan langkah-langkah penerapan pembelajaran Role Play untuk memudahkan siswa mengikuti pelajaran.

5) Pada siklus II dipilih salah satu kelompok sebagai kelompok terbaik I, II,III dan IV dengan kriteria dapat menyelesaikan praktek dalam waktu 30 menit dengan catatan tiap anggota dapat memerankan tugas masing-masing sesuai prosedur dan terjalin kerjasama atau team work yang baik antara anggota yang satu dengan yang lainnya.

Hasil pada siklus II yaitu sebanyak 38 orang dianggap sudah menguasai kompetensi dasar prosedur penanganan tamu tiba di hotel karena memperoleh nilai diatas KKM dengan ketuntasan klasikal 100\%. Hasil belajar siswa mengalami peningkatan sebesar 6,0 dari siklus I, yaitu menjadi 89,5 berada pada kategori sangat baik.

Berdasarkan perbaikan proses pembelajaran pada tindakan siklus II tampak adanya perubahan dan peningkatan aftifitas dan hasil belajar siswa. Hasil refleksi siklus II tanpa mengabaikan faktor-faktor lain yang ikut menentukan pencapaian tujuan pembelajaran, maka secara ketuntasan maupun rata-rata hasil belajar siswa disimpulkan bahwa penerapan model pembelajaran Role Play pada mata pelajaran Frontoffice dengan kompetensi dasar prosedur penanganan barang bawaan tamu tiba di hotel kelas XII AP-3 semester ganjil dikatakan berhasil dan dapat digunakan sebagai rekomendasi bagi guru akomodasi perhotelan yang ingin menerapkan model pembelajaran tersebut. 
Berdasarkan hasil analisis data tentang hasil belajar siswa pada siklus I dan siklus II, dapat dilihat bahwa secara klasikal siswa sudah berada pada kategori baik dan sangat baik. Tidak ada siswa yang tergolong dalam kategori kurang ataupun sangat kurang aktif. Hal ini menandakan bahwa terjadi peningkatan yang signifikan didalam proses pembelajaran penanganan barang bawaan tamu tiba di hotel dengan model pembelajaran Role Play, atau dengan kata lain dapat dikatakan bahwa model pembelajaran Role Play ini dapat meningkatkan hasil belajar siswa pada kompetensi dasar penanganan barang bawaan tamu tiba di hotel pada siswa kelas XII AP-3 SMK Negeri 2 Singaraja Tahun Pelajaran 2017/2018.

Dari hasil angket respon siswa terhadap penerapan model pembelajaran Role Play yang diberikan pada siswa kelas XII AP-3 dapat diketahui bahwa siswa di kelas XII AP-3 memiliki respon yang sangat tinggi yaitu $82,04 \%$.

\section{Simpulan Dan Saran}

Berdasarkan analisis terhadap data hasil penelitian tindakan kelas ini, dapat disimpulkan hal-hal sebagai berikut. Model Pembelajaran Role Play dengan seting belajar kelompok dapat meningkatkan kemampuan dan hasil belajar siswa pada kompetensi dasar prosedur penanganan barang bawaan tamu tiba di hotel pada mata pelajaran Front-office di kelas XII AP-3 Tahun Pelajaran 2017/2018 Semester Ganjil. Ini dilihat dari skor hasil belajar siswa secara klasikal pada siklus I mencapai 83,6 yang berada pada kategori baik. Pada siklus II hasil belajar siswa mengalami peningkatan sebesar $6,0 \%$ dari siklus I, yaitu menjadi 89,5 berada pada kategori sangat baik atau dari $66 \%$ ketuntasan belajar siswa menjadi $100 \%$

Melihat dari uraian tersebut diatas dapat disimpulkan bahwa, kemampuan dan hasil belajar siswa dalam pembelajaran tergolong tinggi dan penerapan model pembelajaran Role Play berhasil meningkatkan kemampuan dan hasil belajar siswa dalam proses pembelajaran Front-office pada kompetensi dasar prosedur penanganan barang bawaan tamu tiba di hotel siswa kelas XII AP-3 SMK Negeri 2 Singaraja tahun pelajaran 2017/2018.

Berdasarkan hasil penelitian tindakan kelas yang peneliti laksanakan dapat dikemukakan saran-saran, sebagai berikut.

1. Bagi Pendidik sebaiknya lebih memahami strategi pembelajaran atapun metode yang ada sehingga dalam kegiatan pembelajaran nantinya dapat menggunakan metode yang tepat dalam kegiatan pembelajaran serta dapat melakukan berbagai variasi model pembelajaran agar siswa dapat aktif dan kreatif mengikuti kegiatan belajar mengajar yang salah satunya adalah model pembelajaran Role Play untuk meningkatkan hasil belajar siswa dalam pembelajaran prosedur penanganan barang bawaan tamu tiba di hotel

2. Mengingat pelaksanaan Penelitian Tindakan Kelas (PTK) ini hanya dua siklus dan validasi instrumen penelitian belum standar, maka kepada guru yang akan meneliti penerapan model pembelajaran Role Play dalam proses pembelajaran diharapkan lebih ditingkatkan kualitasnya baik frekuensi maupun instrumen penelitiannya.

3. Bagi sekolah dapat dijadikan umpan balik untuk meningkatkan efektivitas dan efesiensi pembelajaran dalam meningkatkan kualitas sekolah melalui kinerja guru.

\section{Daftar Rujukan}

Adnyani, L.D.S. dan P.E. Dambayana. (2012). "Penerapan Teknik Role Play Dengan Bantuan Video Pada Mata Kuliah Speaking 2 Untuk Meningkatkan Keterampilan Berbicara Mahasiswa Jurusan Pendidikan Bahasa Inggris Undiksha Tahun Ajaran 2011/2012“. Jurnal Pendidikan Indonesia Vol. 3, No. 1, April 2014.

Dedi Rizkia Saputra. (2015). “Penerapan Metode Role Playing Untuk Meningkatkan Hasil Belajar Ips Pada Siswa Kelas V Sd Negeri 2 Kecemen, Manisrenggo, Klaten”. Jurnal PGSD UNY Vol 2 No 3

Desi Susanty. (2017). "Model Pembelajaran Role Playing Pada Mata Pelajaran Bahasa Indonesia”. Dalam http://Semnasfis.Unimed.Ac.Id E-Issn: 2549-5976 P-Issn: 2549-435x 259 Prosiding Seminar Nasional Tahunan Fakultas Ilmu Sosial Universitas Negeri Medan Tahun 2017

Djamarah, Syaiful Bahri. (2002). Strategi Belajar Mengajar. Jakarta: Rineksa Cipta.

Djamarah, Syaiful Bahri. (2002). Psikologi Belajar. Jakarta: Rineksa Cipta. 
Kanca, I.N. (2006). Metodologi Penelitian Pengajaran Pendidikan Jasmani Dan Olahraga. Singaraja : Universitas Pendidikan Ganesha.

Uno, HamzahB. (2006). Perencanaan Pembelajaran. Jakarta, BumiAksara.

Uno, Hamzah B. (2007). Pengantar Teori Belajar dan PembelajaranCet. II. Gorontalo: Nurul Jannah

Rustiyah, N.K. (1994). Strategi Belajar Mengajar. Jakarta: Bina Aksara.

Sadirman. A.M. (2003). Interaksi dan Semangat Belajar Mengajar. Jakarta: CV. Rajawali.

Tarigan, Arleni. (2016). “Penerapan Model Pembelajaran Role Playinguntuk Meningkatkan Hasil Belajar Ips Siswa Kelas Iii Sd Negeri 013 Lubuk Kembang Sari Kecamatan Ukuiarleni Tarigan". Jurnal Primary Program Studi Pendidikan Guru Sekolah Dasar Fakultas Keguruan Dan Ilmu Pendidikan Universitas Riau | Volume 5 | Nomor 3 | Edisi Khusus HUT PGRI Ke-71 Tanggal 25 November 2016.

Wahyuningsih , Sri Lestari. (2016). "Penggunaan Metode Pembelajaran Role Playing Dalam Meningkatkan Kemampuan Berhitung Penjumlahan Dan Pengurangan Pada Siswa Kelas Vi Slb C1 Dharma Mulia Semarang “. Sekolah Luar Biasa C/C1 Dharma Mulia Semarang

Warsini. (2012). "Model Pembelajaran Role Playing Pada Mata Pelajaran Pkn Untuk Meningkatkan Motivasi Belajar". Jurnal Univ.Lampung Vol 2 No 1 